\author{
Professor emeritus Vladimir-Đuro Degan u trajnom zvanju \\ Sveučilište u Rijeci \\ Dr. sc. Vesna Barić Punda, redovita profesorica \\ Pravnog fakulteta Sveučilišta u Splitu
}

\title{
PITANJE KONTINUITETA REPUBLIKE HRVATSKE S DRŽAVAMA PRETHODNICAMA NA NJEZINU PODRUČJU
}

\author{
UDK: $342.22: 341$ \\ Primljeno: rujan 2017. \\ Izvorni znanstveni rad
}

\begin{abstract}
Povod za ovu raspravu jest skupna tužba (Class Action Complaint) koju je grupa nasljednika i rodbine hrvatskih Židova, Srba i Roma podnijela protiv Republike Hrvatske 31. svibnja 2016. godine Okružnom sudu Sjedinjenih Država za Sjeverni okrug Istočnoga područja Illinoisa. Tužba se zasniva na tvrdnji o apsolutnom identitetu i kontinuitetu Republike Hrvatske s tzv. „Nezavisnom Državom Hrvatskom“ iz Drugog svjetskog rata. U tužbi se od Republike Hrvatske traži odšteta za pretrpljene gubitke žrtava holokausta u ukupnom iznosu od 3.500.000.000 američkih dolara.
\end{abstract}

Ključne riječi: identitet $i$ kontinuitet države, satelitski režimi, Nezavisna Država Hrvatska, eksproprijacija privatne imovine, nepovredivost konzularne imovine

\section{POLAZIŠTE}

Republika Hrvatska, koja se 8. listopada 1991. odvojila od onoga što je još bilo privremeno preostalo od SFRJ (jugoslavenske federacije), stekla sveopće međunarodno priznanje počam od 15. siječnja 1992., a 22. svibnja te godine primljena u članstvo Organizacije Ujedinjenih nacija (UN), nije i ne može biti sljednicom fašističke tvorevine „Nezavisne Države Hrvatske“ (NDH) koju su okupatori Italija i Njemačka stvorili u travnju 1941., a de facto je postojala do kapitulacije Njemačke u svibnju 1945.

Da bi se predmet ove Skupne tužbe razmotrio, potrebno je najprije opisati položaj NDH, a potom pitanja nasljeđivanja prava i dužnosti Republike Hrvatske stjecanjem njezine neovisnosti.

\section{PRAVNI POLOŽAJ NDH}

Vođa hrvatskih ekstremista u zemlji Slavko Kvaternik proglasio je Nezavisnu Državu Hrvatsku u ime poglavnika Ante Pavelića 10. travnja 1941. godine izjavom pročitanom na radiju. Potom je, uz dopuštenje fašističke Italije, tj. njezina Ducea 
Vladimir-Đuro Degan i dr. sc. Vesna Barić Punda: Pitanje kontinuiteta Republike Hrvatske s državama... Zbornik radova Pravnog fakulteta u Splitu, god. 54, 4/2017., str. 783.- 794.

Benita Mussolinija, Pavelić sa skupinom emigranata prešao granicu i došao iz Italije u Zagreb 15. travnja. ${ }^{1}$

Nedugo po kapitulaciji jugoslavenske vojske 17. travnja te godine, njemački Führer Adolf Hitler primio je 20. travnja talijanskoga ministra vanjskih poslova grofa Galeazza Ciana u željezničkoj kompoziciji u Mönichkirchenu blizu Beča. Sutradan je ovaj nastavio razgovore s njemačkim ministrom Ribbentropom u hotelu Imperial u Beču. Bilo je odlučeno da se teritorij Jugoslavije raskomada u korist tih dviju zemalja, te Mađarske i Bugarske, a da se na područjima današnje Republike Hrvatske i Bosne i Hercegovine uspostavi NDH. Kao cijenu za to Italija je prisvojila veći dio istočne obale Jadranskoga mora s unutrašnjošću, gotovo u cijelosti nastanjenima hrvatskim stanovništvom. ${ }^{2}$

Do toga izvanrednoga razvoja događaja ne bi došlo da se u Beogradu nije 27. ožujka te godine zbio vojni udar uperen protiv pristupanja Kraljevine Jugoslavije Trojnom paktu fašističkih sila dva dana prije, tj. 25. ožujka. Prije toga je Njemačka, makar privremeno, zagovarala integritet Jugoslavije, a i fašistička Italija sklopila je 17. ožujka 1937. godine ugovor kojim ga je prihvatila. Tada su Hitler i Mussolini odlučili uništiti i raskomadati Jugoslaviju u kojoj su gledali ostatak Versajskoga poretka iz $1919 .{ }^{3}$ Da nije bilo vojnoga udara u Beogradu, NDH ne bi, makar tada i pod tim uvjetima, bila proglašena.

Fašističke sile snabdjele su samoproglašenoga poglavnika nove države diktatorskim ovlastima po uzoru na „F Führer princip“ u Njemačkoj. ${ }^{4}$ Bio je to način da taj režim služi njihovim interesima, ali i da one izbjegnu obvezama okupanata iz članaka 42-56 Haškoga pravilnika o zakonima i običajima rata na kopnu iz 1907., kakve su imale npr. u okupiranoj Srbiji. Poglavnik je u svojim rukama držao svu zakonodavnu, izvršnu i sudsku vlast. Zakonske odredbe donosio je sam ili su ih po njegovu ovlaštenju donosili ministri koje je on sve sam imenovao. Jednako je bilo i $\mathrm{s}$ imenovanjem sudaca. Sam je prihvaćao i ratificirao međunarodne ugovore.

Od triju uvjeta nastanka i postojanja nove države: stanovništva i teritorija, NDH nije bila snabdjevena onim trećim: suverenom vlašću. To se napose odrazilo u vođenju vanjske politike i u prihvaćanju ugovornih obveza.

Na sastanku na Brenneru 2. lipnja 1941., Hitler i Mussolini odlučili su da NDH pristupi Trojnom paktu između Njemačke, Italije i Japana od 27. rujna 1940. Tome je paktu pola godine prije bez uspjeha pristupila Kraljevina Jugoslavija. Pristupanje

1 Vidi pobliže: Vladimir-Đuro DEGAN: Hrvatska država u međunarodnoj zajednici, „Razvitak njezine međunarodnopravne osobnosti tijekom povijesti“, Zagreb, 2002., str.159-161, i tamo navedenu drugu literaturu; Jozo TOMASEVICH: Rat i revolucija u Jugoslaviji 1941-1945, „Okupacija i kolaboracija“", Zagreb, 2010., str. 263-339.

2 Vidi o tijeku pregovora, o ustanovljenju NDH i o njezinim granicama, V. Đ. DEGAN: „Pravni aspekti i političke posljedice Rimskih ugovora od 18. svibnja 1941. godine“, Zbornik radova Pravnog fakulteta u Splitu 2008., br. 2, str. 265-278.

Vidi pojedinosti: Bogdan KRIZMAN: Ante Pavelić i ustaše, Zagreb, 1978., str. 344-363.

4 Cf., - Ernst NOLTE: "Three Faces of Fascism", Action française, Italian Fascism, National Socialism, Mentor Books, New York, 1969., pp. 462-466; William SHIRER: "The Rise and Fall of the Third Reich", A History of Nazi Germany, A Fawcett Crest Book, 1959., pp. 132-133. 
Vladimir-Đuro Degan i dr. sc. Vesna Barić Punda: Pitanje kontinuiteta Republike Hrvatske s državama... Zbornik radova Pravnog fakulteta u Splitu, god. 54, 4/2017., str. 783.- 794.

je potom izvršeno poglavnikovom odlukom putem Protokola koji je on potpisao u Veneciji 15. lipnja 1941.

Već sutradan po njemačkoj agresiji na Sovjetski Savez od 22. lipnja 1941., poglavnik je ,zamolio“ Führera da upotrijebi hrvatske dobrovoljačke formacije u budućim vojnim operacijama u toj zemlji. Ta molba bila je uslišana, iako nikada nije uslijedila formalna objava rata NDH Sovjetskom Savezu. Hrvatski narod zaista nije imao nikakvoga interesa da voljom poglavnika podnosi ljudske žrtve, sudjelujući u suludoj nacističkoj agresiji radi osvajanja ,životnoga prostora“ za germansku rasu u slavenskoj Rusiji.

Do pristupa Paktu protiv Komunističke internacionale (Kominterne) od 25. studenoga 1936., došlo je na inicijativu iz posebnog Hitlerova vlaka, koju su i Hrvatska i Slovačka bile spremno prihvatile. Taj je Pakt prije njegova formalnoga isticanja bio obnovljen Protokolom u Berlinu 25. studenoga 1941. na daljih pet godina. Tom su mu prilikom, uz NDH, pristupile još i Bugarska, japanski marionetski režim u Kini, Danska, Finska, Rumunjska i Slovačka. Stranke toga Pakta prije toga su, uz tri sile Osovine, bili Mandžukuo i Španjolska.

Ali je sve to imalo još kobnije kasnije posljedice. Nakon japanske agresije na Pearl Harbor 7. prosinca 1941., njemačko ministarstvo vanjskih poslova „,predložilo“ je da NDH i Slovačka objave rat Sjedinjenim Državama, a uz njih još i Britaniji. To je spremno bilo obavljeno na sjednici Vlade u Zagrebu pod predsjedanjem poglavnika 14. prosinca te godine. ${ }^{5}$

Iz svega gornjega proizlazi da NDH nije imala vlastite vanjske politike. Svaki zahtjev ili interes Njemačke i Italije ta je država morala stavljati iznad svojih nacionalnih interesa. A Hitler i Mussolini ostvarivali su te interese putem naloga poglavniku, kojega su u tu svrhu bili opskrbili diktatorskim ovlastima u toj državi.

Gornje je bilo razlogom što je Nezavisna Država Hrvatska dobila međunarodno priznanje od veoma ograničenoga kruga država. Radilo se gotovo isključivo o silama Osovine i njihovim saveznicima ili satelitima. De jure je kao država bila priznata od jedanaest sljedećih zemalja: Njemačke, Italije, Japana, Mađarske, Bugarske, Slovačke, Rumunjske, Španjolske, Finske, Danske i japanske satelitske tvorevine „Carstva Mandžukuo“. Održavala je diplomatske odnose s ne više od devet država, i to s Njemačkom, Mađarskom, Rumunjskom, Italijom, Bugarskom, Finskom, Španjolskom, Slovačkom te, pred kraj rata, s Japanom.

Sve ostale države u svijetu produljile su s priznanjem Kraljevine Jugoslavije i nisu s njome prekidale diplomatske odnose, osim Sovjetskoga Saveza između travnja i 22. lipnja 1941. Ne povlačeći de jure priznanje, Švicarska je s NDH i Slovačkom uspostavila de facto odnose.

Nakon Drugoga svjetskog rata, mirovnim ugovorima ili na drugi način, Italija, Mađarska, Bugarska i dvije države nastale na tlu Njemačke, retroaktivno su priznale neprekinuti kontinuitet jugoslavenske države kroz čitavo trajanje toga rata.

5 B. KRIZMAN: Pavelić između Hitlera i Mussolinija, Zagreb, 1980., str. 236-245. 
Poslijeratne vlade tih zemalja, zajedno s onom japanskom, time su smatrale da su „Carstvo Mandžukuo“, Slovačka i NDH bile njihove satelitske tvorevine i da nikada nisu bile suverene države. Na taj su način sve one neizravnim putem priznale da su tijekom toga rata na čitavom području napose Kine i Jugoslavije imale samo prava i dužnosti okupanta prema međunarodnom ratnom pravu. Time su one neizravno retroaktivno poništile svoja prijašnja priznanja tih tvorevina, kao da do njih nikada nije ni bilo došlo. ${ }^{6}$ Nikada ni kasnije one nisu promijenile te svoje stavove. I ostale države koje su preuzele odgovornost za kršenje Briand-Kelloggova pakta iz 1928., a nisu ostvarivale nikakvu vlast u okupiranoj Jugoslaviji i drugdje, također su neizravno unazad poništile svoje priznanje tih tvorevina. ${ }^{7}$

Zanimljivo je na koncu ustanoviti činjenicu da jedino Španjolska nije nikada retroaktivno poništila svoje priznanje NDH pa, koliko nam je poznato, ni nakon smrti generalisimusa Franca 1975. ${ }^{8}$

NDH je ustrojila regularnu vojsku (domobrane), zasnovanu na vojnoj obvezi (novačenju), kao i stranačku Ustašku vojnicu po uzoru na Waffen SS-divizije u Njemačkoj. Sve te oružane snage bile su u talijanskoj okupacijskoj zoni do kapitulacije Italije 8. rujna 1943. pod isključivim nadzorom te zemlje, a u onoj njemačkoj do konca rata pod zapovjedništvom ili u sastavu Njemačke vojske. ${ }^{9}$ Vojni tribunal Sjedinjenih Država koji je zasjedao u Nürnbergu u slučaju talaca (the Hostage Trial) br. 47 iz 1948. pravilno je zaključio da je „hrvatska vlada bila satelitska vlada i što god je ona učinila bilo je učinjeno za Nijemce“. ${ }^{10}$

Sve se to primjenjuje i na žrtve jasenovačkoga logora, unatoč činjenici što su, za razliku od većine koncentracijskih logora u Europi, tim i drugim logorima u NDH neposredno upravljale ustaške vlasti. Rasne zakone diktirali su eksperti iz njemačkoga poslanstva u Zagrebu, a progon Srba hrabrio je Adolf Hitler već pri prvom sastanku s Pavelićem u lipnju 1941. Uostalom, da se Njemačka držala svojih obveza iz Haškoga pravilnika iz 1907., ne samo da ne bi ustanovila satelitski režim u dijelu Jugoslavije, nego bi na teritoriju pod svojom odgovornošću bila dužna spriječiti najteže zločine protiv čovječnosti.

U doba proglašenja NDH možda je većina njezinih stanovnika željela neovisnu državu i raspad nepopularne jugoslavenske monarhije. Ali napose nakon sklapanja Rimskih ugovora o granicama s Italijom od 18. svibnja 1941., brutalnoga provođenja rasnih zakona protiv Židova i Roma, masovnih progona i ubojstava Srba, te vladavine terora nad svim stanovnicima te zemlje, radikalno su se umanjile te simpatije. S obzirom na to da nije postojao antifašistički otpor organiziran od

6 To je značilo da su te zemlje preuzele odgovornost za sve akte vlasti tih tvorevina i da su priznale da su te vlasti djelovale kao organi okupacijskih sila.

7 To može proizići iz tekstova mirovnih ugovora sklopljenih u Parizu 1947. s Finskom i Rumunjskom.

$8 \quad$ V. Đ. DEGAN: Hrvatska država u međunarodnoj zajednici, str.170-174.

9 Vidi opširnije, J. TOMASEVICH, op. cit., str. 460-522.

10 Cf., Law Reports of Trials of War Criminals, Volume VIII, case No. 47, London, 1949., p. 74. Vidi u prilogu tekst presude Wilhelm List $i$ drugi koji se odnosi na „Pravni položaj „Hrvatske vlade““”, pp. 72 74. 
Vladimir-Đuro Degan i dr. sc. Vesna Barić Punda: Pitanje kontinuiteta Republike Hrvatske s državama... Zbornik radova Pravnog fakulteta u Splitu, god. 54, 4/2017., str. 783.- 794.

demokratskih snaga, oni koji su se htjeli boriti protiv okuptora nisu imali izbora nego se pridružiti Narodnooslobodilačkoj borbi koju su organizirali komunisti. To je pred konac i nakon toga rata dovelo do novoga vala nasilja protiv tzv. ,klasnih neprijatelja“.

\section{PRAVNI KONTINUITET REPUBLIKE HRVATSKE SA SFRJ DO NJEZINA RASPADA}

Revolucionarni organi nove vlasti pod vodstvom komunista još su u tijeku rata proveli neke duboke reforme u državi. Na Drugom zasjedanju Antifašističkoga vijeća narodnoga oslobođenja Jugoslavije (AVNOJ-a) u Jajcu 29. studenoga 1943., Jugoslavija je bila preustrojena u federaciju šest federalnih jedinica: Srbije, Hrvatske, Slovenije, Makedonije, Crne Gore te mnogonacionalne Bosne i Hercegovine. Nakon rata, u sastavu Srbije ustanovljene su dvije autonomne jedinice: Vojvodina i Kosovo. Granice koje su tada bile zacrtane između tih jedinica (osim onih između Vojvodine i uže Srbije) postale su u devedesetim godinama prošloga stoljeća granice novih država.

U 1944. godini izbjeglička vlada Kraljevine Jugoslavije u Londonu sklopila je dva sporazuma s revolucionarnom vlašću nastalom u zemlji (sporazumi TitoSubašić od 16. lipnja na Visu i od 1. studenoga u oslobođenom Beogradu). Drugim sporazumom dokinuto je dvojstvo vlasti u zemlji i u inozemstvu, a strane zemlje akreditirale su svoje diplomatske predstavnike kod Kraljevskoga namjesništva ustanovljenoga temeljem tih sporazuma. ${ }^{11}$ Jedinstvena jugoslavenska delegacija sudjelovala je na Osnivačkoj konferenciji Organizacije UN (UNCIO) od 25. travnja i 26. lipnja 1945. u San Franciscu. Tom je prilikom ona potpisala Povelju UN-a kao jedna od 51 iskonske članice te organizacije.

Unatoč tim koracima, komunisti su u čitavoj Jugoslaviji i u svakoj od republika uspjeli izolirati i onemogućiti svaku demokratsku opoziciju. Izbori za Ustavotvornu skupštinu koja je proglasila federativnu republiku održani su samo s jednom listom Narodnoga fronta u kojoj su dominirali komunisti.

Hrvatska se od početka antifašističke borbe u godinama Drugog svjetskog rata razvijala kao federalna republika u sastavu Jugoslavije. Ustanici u Hrvatskoj aktivno su se borili protiv njemačkih i talijanskih okupatora, kao i njihove tvorevine NDH.

Republika Hrvatska proglasila je svoju samostalnost i neovisnost 1991., odvajajući se od ostatka Jugoslavije kao njezina bivša federalna jedinica, te prema saveznim i republičkim propisima tada na snazi. Jednako je bilo i s drugim državama nastalima raspadom SFRJ i to sa Slovenijom, Bosnom i Hercegovinom, Makedonijom, Crnom Gorom, Srbijom i Kosovom.

11 Vidi više pojedinosti - Ferdo ČULINOVIĆ: Državnopravna historija jugoslavenskih zemalja XIX. $i X X$. vijeka, druga knjiga, II. temeljito prerađeno izdanje, Zagreb, 1959., str. 370-376. Poput većine drugih pisaca iz toga doba, Culinović je smatrao da je nova Jugoslavija bila u odnosu na predratnu monarhiju sasvim nova država. On nije uočavao razliku između priznanja nove države i nove vlade. 
I taj pravni položaj Hrvatske kao jedne od država sljednica raspale SFRJ isključuje njezinu odgovornost za zločine koje su Njemačka, Italija i njihova satelitska tvorevina NDH počinile u Drugom svjetskom ratu, dakle pola stoljeća prije naših dana. ${ }^{12}$

Ove činjenice potvrđuju Izvorišne osnove Ustava Republike Hrvatske danas na snazi u kojima se, između ostaloga, navodi sljedeće:

„Izražavajući tisućljetnu nacionalnu samobitnost $i$ državnu opstojnost hrvatskoga naroda, potvrđenu slijedom ukupnoga povijesnoga zbivanja u različitim državnim oblicima te održanjem i razvitkom državotvorne misli o povijesnom pravu hrvatskoga naroda na punu državnu suverenost, što se očitovalo:...

- u uspostavi temelja državne suverenosti u razdoblju drugoga svjetskog rata, izraženoj nasuprot proglašenju Nezavisne Državne Hrvatske (1941.) u odlukama Zemaljskoga antifašističkog vijeća narodnog oslobođenja Hrvatske (1943.), a potom u Ustavu Narodne Republike Hrvatske (1947.) i poslije u ustavima Socijalističke Republike Hrvatske (1963.-1990.), na povijesnoj prekretnici odbacivanja komunističkog sustava i promjena međunarodnog poretka u Europi, hrvatski je narod na prvim demokratskim izborima (godine 1990.), slobodno izraženom voljom potvrdio svoju tisućgodišnju državnu samobitnost. Novim Ustavom Republike Hrvatske (1990.) i pobjedom u Domovinskom ratu (1991.-1995.) hrvatski je narod iskazao svoju odlučnost $i$ spremnost za uspostavu i očuvanje Republike Hrvatske kao samostalne $i$ nezavisne, suverene i demokratske države."

\section{KRITIKA NAVODA IZ SKUPNE TUŽBE}

Podnesena skupna tužba zasniva se na kontradiktornim argumentima čiji se učinci uzajamno pobijaju.

U dijelu te tužbe pod točkama 13. do 18. tužitelji se pozivaju na sastanak u Wannseeu 20. siječnja 1942. pod predsjedanjem SS-Obergruppenfuhrera Reinharda Heydricha. Sastanak je održan nakon njemačke objave rata Sjedinjenim Američkim Državama kada su nacisti izgubili sve, čak i propagandne obzire u brutalnom provođenju politike holokausta, tj. smaknuća Zidova u svim dijelovima Europe koje je okupirao Reich.

Ni satelitska vlast NDH nije bila pozvana da sudjeluje na tome ili nekom drugom važnom sastanku, ali se podrazumijevala njezina dužnost da i u tome pogledu izvršava sve njemačke naloge. Ona se po brutalnosti počinjenih zločina nastojala

12 Vidi V. Đ. DEGAN: Hrvatska država u međunarodnoj zajednici, str. 239-262. 
čak isticati u provođenju tih naloga u odnosu na Nijemce. To, međutim, dokazuje točnost glavnoga zaključka američkoga Vojnog tribunala u Hostage Trialsu da je „hrvatska vlada bila satelitska vlada i što god je ona učinila bilo je učinjeno za Nijemce“.

U toj skupnoj tužbi u isto se vrijeme površno i bez pravno relevantnih dokaza tvrdi da je „Republika Hrvatska“ izvršila zločine u Drugom svjetskom ratu i da je od 1941. do 1945. bila članica sila osovine (sic!). U točki 19. dalje se tvrdi, opet bez dokaza: „Kad je Tito preuzeo Jugoslaviju nakon rata, u zemlji je proglašen komunizam. Nove hrvatske vlasti pod vodstvom Franje Tuđmana odmah su donijele zakone s rasističkim karakteristikama slične onima iz 1941., te su ponovo organizirale teror nad manjinama“. Time tužitelji zastupaju apsolutni identitet NDH s današnjom Republikom Hrvatskom, ali za to ne iznose dokaze.

1. Najprije valja ponoviti činjenicu da između tzv. NDH i današnje Republike Hrvatske ne postoji nikakav identitet, a ni pravni kontinuitet. NDH je voljom okupatora obuhvaćala područje današnje Republike Hrvatske (osim obale na Jadranskom moru sa zaleđem koje je prisvojila fašistička Italija), te uz nju čitavu Bosnu i Hercegovinu, Srijem tj. prostor između rijeka Dunava i Save do Beograda (Zemuna). Srijem je danas kao dio Vojvodine u sastavu Republike Srbije.

2. Kapitulacijom nacističke Njemačke 8 . svibnja 1945. i povlačenjem njemačkih oružanih snaga nestala je svaka organizirana vlast NDH na tome prostoru. To je daljnji dokaz da taj satelitski režim nije mogao nadživjeti nacističku vlast koja ga je ustanovila i da stoga nije imao obilježja države kao punopravnog subjekta međunarodnoga prava. Sve do proglašenja suverenosti i samostalnosti Republike Hrvatske 25. lipnja 1991., na njezinu teritoriju djelovala je samo vlast Socijalističke Republike Hrvatske u sastavu jugoslavenske federacije. Nikakva Nezavisna Država Hrvatska u samoj Hrvatskoj ili u Bosni i Hercegovini tada nije postojala u nikakvom obliku. Te činjenice također pobijaju zahtjev iz Skupne tužbe o kontinuitetu između NDH i Republike Hrvatske.

3. U tijeku Drugoga svjetskog rata na oslobođenom području današnje Republike Hrvatske postupno su se osnivali organi vlasti pod vodstvom komunista. To je bio začetak stvaranja i drugih federalnih jedinica u Jugoslaviji. Na početku je Jugoslavija, po ugledu na Sovjetski Savez, bila veoma centralizirana država jer su se sve važne političke odluke za čitavu tu državu donosile u vrhu Komunističke partije u Beogradu. Svi državni organi na razini Federacije, kao i svi partijski i državni organi na razini federalnih jedinica, bili su transmisije u provođenju odluka partijskoga vrha u Beogradu.

Ali su se tijekom vremena stvari bitno promijenile. Jugoslavija se federalizirala usporedo kako se federalizirao Savez komunista Jugoslavije kao njegova vodeća politička snaga. Republike i pokrajine stekle su mnogo više autonomije u odlučivanju negoli prije. Time je i Hrvatska dobila mogućnost da, nakon pada Berlinskoga zida 1989., postane neovisna država. Tada je Savez komunista Hrvatske odlučio dopustiti višestranačje i potom su raspisani prvi višestranački demokratski izbori u proljeće 1990. 
Sve gornje isključuje svaki kontinuitet u vremenu i prostoru između NDH i današnje Republike Hrvatske.

4. Također, s obzirom na gornje, Republika Hrvatska nosi pravni kontinuitet sa Socijalističkom (prije „narodnom“, a još prije „federalnom“) Hrvatskom koja se u tijeku Drugoga svjetskog rata borila protiv tzv. „Nezavisne Države Hrvatske“ i njezine zločinačke politike prema Židovima, Romima i Srbima. Franjo Tuđman se u to vrijeme kao partizan aktivno borio protiv te vlasti i protiv progona i zločina koje je ona činila.

Uostalom, nemoguće je i pretpostaviti da bi Sjedinjene Države 7. travnja 1992. službeno priznale Hrvatsku, Bosnu i Hercegovinu i Sloveniju da je neka od njih imala fašistički poredak zasnovan na rasnoj ideologiji koje su im u Drugom svjetskom ratu nametnuli okupatori. Ako Okružni sud za Sjeverni okrug Istočnoga područja Illinoisa ima u tome pogledu neke sumnje, on može o tome uputiti pitanje Ministarstvu vanjskih poslova (State Department) Sjedinjenih Država.

Republika Hrvatska, Bosna i Hercegovina i Republika Slovenija primljene su u članstvo Ujedinjenih nacija 22. svibnja 1992. Članak 4(2) Povelje predviđa da, osim iskonskih članova (poput bivše SFRJ): ,članovima Ujedinjenih nacija mogu postati sve ostale miroljubive države koje prihvate obveze sadržane u ovoj Povelji i koje su po ocjeni Organizacije sposobne i voljne izvršavati te obveze“. U Savjetodavnom mišljenju iz 1948. O uvjetima za primanje neke države u članstvo UN Međunarodni sud u Haagu je zaključio: „Predviđenih uvjeta, dakle, ima pet: treba (1) biti država; (2) biti miroljubiva; (3) prihvatiti obveze iz Povelje; (4) biti sposobna izvršavati te obveze; (5) biti voljna to učiniti““. ${ }^{13}$ Hipotetski uzevši, NDH, dok je trajala, nije bila u stanju ispuniti ni jedan od tih uvjeta. Republika Hrvatska i Bosna i Hercegovina ispunile su ih u svibnju 1992. sve. I zbog toga je neodrživa tvrdnja o identitetu i kontinuitetu između tih tvorevina.

Ako na koncu skupni tužitelji ostaju pri tvrdnji da je Republika Hrvatska, nakon proglašenja neovisnosti 1991., donosila zakone s rasističkim karakteristikama sličnima onim iz 1941., neka Sudu podastru njihove tekstove. Ali je sasvim neprimjereno na toj nedokazanoj tvrdnji bez argumenata tražiti odštetu od 3.500.000.000 dolara.

$*$

\section{SUDBINA NEPOKRETNE PRIVATNE IMOVINE}

Navodni cilj ove tužbe jest postizanje naknade pred američkim sudom za oduzetu imovinu u tijeku Drugoga svjetskog rata.

U NDH privatna se imovina nacionalizirala primjenom rasnoga zakonodavstva jedino u židovskom vlasništvu. Dana 10. listopada 1941. donesena je Zakonska odredba o podržavljenju imetka Židova i židovskih poduzeća. Prema osobama

13 Cf., I.C.J. Reports, 1948., p. 62. 
označenima kao Židovi primjenom rasnih zakona o državnoj pripadnosti ona je izvršena temeljito i sustavno. Veoma je često to izvlašćivanje bilo popraćeno fizičkom likvidacijom vlasnika i njihovih obitelji. Iako su i Romi spadali u skupinu „državnih pripadnika“ a ne "državnih građana”, i bili su izloženi ubojstvima bez osobne krivnje, njihova imovina nije bila obuhvaćena tim mjerama. Vjerojatno se pošlo od činjenice da oni nisu ni posjedovali imovinu vrijednu nacionalizacije. Srbi su uz prve dvije skupine ponekad bili izloženi diskriminaciji u stanovanju u dijelovima gradova i drugim oblicima nasilja, ali ni njihova imovina nije bila obuhvaćena takvim diskriminatorskim propisima. U praksi je, međutim, bilo mnogo slučajeva samovoljne eksproprijacije i otimačine stanova, imanja i pokretnina, naročito onih Srba koje je režim uzimao svojim neprijateljima.

Dolaskom komunista na vlast, u čitavoj Jugoslaviji nisu ukinuti samo rasni zakoni, nego i čitavo predratno zakonodavstvo, osim iznimaka pod nedovoljno precizno propisanim uvjetima. Već se 3. veljače 1945. donosi Odluka koja je 23. listopada 1946. upotpunjena konačnim Zakonom o nevažnosti pravnih propisa donesenih prije 6. travnja 1941. i za vrijeme neprijateljske okupacije.

Temeljno načelo bilo je da su se pravni propisi doneseni za okupacije smatrali nepostojećima. S druge strane, propisi prihvaćeni prije 6. travnja 1941. izgubili su pravnu snagu ex nunc. Ali njihov sadržaj mogao se primjenjivati kao pravno pravilo jedino u odnosima koji nisu bili uređeni novim pravilima i u slučajevima da nisu bili suprotni njima ili nisu bili suprotni načelima novoga ustavnog poretka.

Taj važan zakon potvrdio je činjenicu da između NDH (i režima u drugim dijelovima Jugoslavije koje je nametnuo okupator) i predratne i poslijeratne jugoslavenske države nije postojao ni identitet, a ni kontinuitet. Ali postojao je identitet same jugoslavenske države između njezina proglašenja 1. prosinca 1918. i proljeća 1992. kada se raspala. Predratna i poslijeratna Jugoslavija bila je jedna država kao subjekt međunarodnoga prava i u pogledu njezinih obveza prema međunarodnom pravu. U pogledu unutarnjega pravnoga poretka postojao je očit diskontinuitet između Kraljevine Jugoslavije i njezina socijalističkoga režima nakon 1945.

Komunistički režim drastično je ograničio pravo privatnoga vlasništva. Te sve mjere usvojene su za čitavu Jugoslaviju i imale su općenitu primjenu na jugoslavenske građane i na strance. One nisu bile diskriminatorske naravi.

U 1946. usvojen je savezni Zakon o nacionalizaciji privatnih privrednih poduzeća kojemu je 1948. slijedio Zakon o njegovim izmjenama i dopunama. Tim mjerama nacionalizirana je gotovo čitava privreda Jugoslavije od rudarstva i brodogradnje do bankarstva, osiguranja i trgovine na veliko. Amandmanima iz 1948. nacionalizacija je proširena na sva ostala poduzeća važna za saveznu ili republičku privredu, kao i na zdravstvene ustanove, kulturne objekte i dr. Konačno, Zakonom o nacionalizaciji najamnih zgrada i građevinskog zemljišta iz 1958. taj proces je bio završen. Tu se nacionalizirala privatna imovina u gradovima od ogromne vrijednosti, ali su bivši vlasnici dobili pravo da traže stanovitu naknadu. 
Tako je došlo do situacije da su, napose Židovima, nacionalizirane nekretnine od vlasti NDH temeljem Zakonske odredbe o podržavljenju imetka Židova i židovskih poduzeća. Potom su akti nacionalizacije i sam taj Zakon proglašeni nepostojećima, da bi se na koncu takve nekretnine nacionalizirale primjenom jugoslavenskoga Zakona o nacionalizaciji najamnih zgrada i građevinskog zemljišta iz 1958. koji nije bio rasistički propis i imao je opću primjenu.

Te su situacije toliko raznorodne da dobra administracija pravde traži individualni pristup svakom slučaju za sebe. Pribjegavanje načelu prethodnoga iscrpljenja domaćih lijekova tu se ne može izbjeći, čak ako, strogo govoreći, ono nije obvezatno pravno pravilo prema zakonodavstvu Sjedinjenih Država. Pojedinačni tužitelj morao bi podnijeti svoj zahtjev u državi u kojoj se njegovo nacionalizirano vlasništvo nalazi (načelo locus in quo), dakle bilo u Hrvatskoj, Bosni i Hercegovini ili Srbiji. Ne predstavlja razumno rješenje u proglašenju današnje Republike Hrvatske genocidnom i fašističkom tvorevinom i u dosuđivanju na njezin teret globalne svote od 3.500.000.000 američkih dolara, a da se sudskim putem nisu utvrdili položaj svakoga nacionaliziranog objekta, okolnosti oduzimanja i današnja vrijednost imovine u pitanju. Prihvaćanje sadašnje Skupne tužbe predstavljalo bi ismijavanje pravde.

Nakon raspada jugoslavenske federacije, njezine države sljednice pristupile su procesu denacionalizacije. U Republici Hrvatskoj osnovni je propis Zakon o naknadi za imovinu oduzetu za vrijeme jugoslavenske komunističke vladavine iz 1996. s kasnijim izmjenama. Oduzeta imovina vraća se prijašnjim vlasnicima ili njihovim nasljednicima prvog nasljednog reda, $\mathrm{i}$ to: $\mathrm{u}$ naravi, $\mathrm{u}$ dionicama i udjelima trgovačkih društava, kao i u novcu i obveznicama.

Za slučaj da Sud usvoji ovu skupnu tužbu, tužitelji u prvoj alternativi predlažu Sudu jedan od načina izvršenja presude:

„U prvoj odredbi sud može uvažiti da se „poslovna aktivnost Hrvatske u Sjedinjenim Državama "dokazuje postojanjem hrvatskih konzulata u sljedećim gradovima, ali ne ograničavajući se samo na njih: New York, Chicago, Los Angeles, Kansas City, New Orleans, Pittsburgh, Seatle, Houston i Ancorage. Ti konzulati pogoduju turizmu i drugim poslovnim aktivnostima od kojih korist ima Hrvatska. “

Tome zahtjevu valja pridodati važan komentar. Iako među konzularnim funkcijama prema članku 5 (b) i (c) Bečke konvencije iz 1963. spada promicanje razvoja trgovačkih i ekonomskih odnosa između države šiljateljice i države primateljice, $u$ što je uključen i turizam, konzularni se uredi ne bave privrednim djelatnostima putem kojih bi ostvarivali dobit i iz koje bi se mogli nadoknaditi gubici tužitelja.

Još je važnija činjenica što su Sjedinjene Američke Države i Republika Hrvatska stranke Bečke konvencije o konzularnim odnosima iz 1963. godine. Prema njezinu 
članku 31., konzularne prostorije, namještaj u njima, imovina konzularnoga ureda, kao i njegova prijevozna sredstva nepovredivi su i ne mogu biti predmetom rekvizicije. Propisi o nepovredivosti još su stroži glede diplomatske imovine temeljem članka 22. Bečke konvencije o diplomatskim odnosima iz 1961.

Ta imovina, pod općim uvjetom da se ne koristi u komercijalne tj. gospodarske svrhe, uživa u državi primateljici imunitet od sudbenosti i od sredstava ovrhe. U nju, između ostaloga, spada imovina, uključujući bankovne račune, koja se koristi ili je namijenjena korištenju za potrebe diplomatske, konzularne ili specijalne misije države šiljateljice, odnosno u slične svrhe. Tako propisuje članak 21. Konvencije UN-a o sudbenom imunitetu država i njihove imovine iz 2004. godine. Ta Konvencija kao ugovorni instrument još nije stupila na snagu, ali ona u tome propisu potvrđuje pravilo običajnoga prava na snazi.

Glede tih vrsta državne imovine čak i izričit pristanak na sudbenost države primateljice ne podrazumijeva pristanak na sredstva ovrhe. To potvrđuju i odgovarajući članci Bečkih konvencija iz 1961. i 1963. godine.

\section{THE QUESTION OF CONTINUITY OF THE REPUBLIC OF CROATIA WITH THE PREDECESSOR STATES ON IT SOIL}

The incentive for the present paper was the Class Action Complaint submitted to the US District Court for the Northern District of Illinois Easter Division against the Republic of Croatia on 31 May 2016. The plaintiffs were victim survivors and hairs of Croatian Jews, Serbs and Roma who were deprived of their property and possessions as a result of the Holocaust allegedly conducted by the present Republic of Croatia during World War II. The Plaintiffs claim the lump sum of 3,500.000.000 US\$.

The rationale of this case is the alleged continuity in international personality of the Republic of Croatia with the so-called "Independent State of Croatia" (NDH), established by the occupants of Yugoslavia Italy and Germany during that period of time. Such a continuity and identity does not exist for following reasons:

This Class Action complaint is based on contradictory arguments which eliminate one another. In parts 13 to 18 of its text the Plaintiffs invoke the Wannssee meeting of high ranking SS and Gestapo officials, convened by SS-Obergruppenfuhrer Reinhard Heidrich on 20 January 1942. The meeting was organized shortly after German declaration of war to the United States when Nazis lost all constraints, even for propaganda purposes, in brutal execution of the Holocaust, i.e. the liquidation of Jews in all parts of Europe occupied by the Reich.

However, the satellite Government of the NDH was not invited to participate in this or in other important meetings to this end. Its duty was implicitly understood to carry out all German orders. Ustaše even distinguished them before Germans in brutal execution of that policy. This fact confirms the truthfulness of the conclusions of the U.S. Military Tribunal in Hostage Trials cited above that: "the Croatian Government was a satellite Government and whatever was done by them was done for the Germans".

On the other hand, in this Class Action complaint the Plaintiffs contend ostensibly and without convincing arguments that "the Republic of Croatia" (meaning the present Croatian State) conducted the Holocaust during World War II, (sic!) and that: "From 1941 to 1945, Croatia was 
a member of the Axis Powers. Croatia committed genocide against its Jewish, Serbian, and Roma citizens..." In paragraph 19 it was furthermore asserted: "When Tito took over Yugoslavia after the war, communism was proclaimed throughout the country. The new Croatian authorities under the leadership of Franjo Tudjman, immediately adopted laws with racial characteristics similar to those of 1941, and re-organized state terror against minorities." By these allegations the Plaintiffs assert the absolute identity between the NDH and the present Republic of Croatia but they did not prove it. They ignored the following facts:

1. First of all, it must be repeated that between the so-called "Independent State of Croatia" and today's Republic of Croatia there exists neither identity nor legal continuity. By the will of occupants that puppet State embraced the territory of the present Republic of Croatia (except parts of the Adriatic coast with its hinterland), the entire Bosnia-Herzegovina and Sirmium (Srijem) i.e. the territory between rivers of Danube and Sava up to the suburb of Belgrade (Zemun). Croatia and Bosnia-Herzegovina are now independent States and UN members, and Sirmium as a part of Voyvodina, is integrated into the Republic of Serbia.

2. Upon the capitulation of Nazi Germany on 8 May 1945 and after the withdrawal of all its troops from Yugoslavia any authority of the NDH disappeared in the respective territories. This is another proof that this satellite regime could not survive the Nazi power that created it. For this reason the NDH did not possess the qualities of a sovereign State, and of genuine subject of international law.

In the period between May 1945 and the proclamation of independence of the Republic of Croatia on 25 June 1991 only the regime of the Socialist Republic of Croatia within the Yugoslav Federation was present on its territory. No Independent State of Croatia in Croatia itself or in BosniaHerzegovina existed then in any form. These facts also contradict the claim from the Class Action Complaint of the continuity between the NDH and the Republic of Croatia.

3. During World War II were progressively established on the liberated territories of Croatia new State organs under the leadership of Communists. In the same way appeared organs which were the nucleus of other federal entities within Yugoslavia. In the beginning the entire Yugoslavia, like the Soviet Union, was a very centralized State. All important political decisions for the entire Federation were made on the top of the Communist party of Yugoslavia in Belgrade. All State organs on the Federal level and all Party and State organs on the level of federal units were not more than transmissions in carrying out the top party decisions made in Belgrade.

However, in the course of time the situation deeply evolved. The Republics and Autonomous Provinces acquired much higher level of self rule in decision-making. Hence, Croatia got the chance after the fall of Berlin Wall in 1989 to become an independent State. In that process it was the League of Communists of Croatia that acquiesced on the multi-party system and first democratic elections for the Croatian parliament (Sabor) were organized in spring 1990.

All the above facts exclude any claim for continuity in time and space between the NDH and the present Republic of Croatia.

4. On the basis of the above facts the Republic of Croatia is the continuous State of the Socialist (before that "People's Republic", and still before "federal") Croatia within the Yugoslav Federation, that during World War II fought against the "Independent State of Croatia" and its criminal policy directed against Jews, Roma and Serbs. Franjo Tuđman was at that time partisan and an active combatant against that power and persecutions and crimes committed by it.

Key words: State identity and continuity; Puppet regimes, Independent State of Croatia; Expropriation of private property; Immunity of consular property 